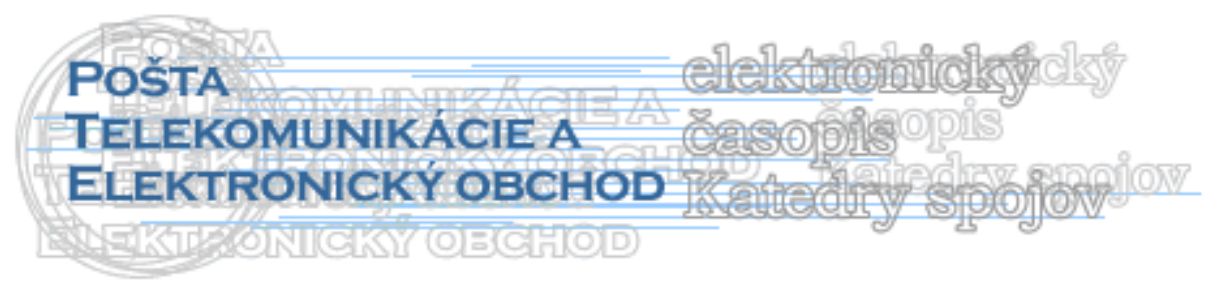

\title{
ASPEKTY REALIZÁCIE ELEKTRONICKÉHO OBCHODU
}

\author{
Juraj Vaculík ${ }^{1}$
}

Výraz web sídlo (web-site) sa stal vel'mi populárny a mnoho l’udí kedysi verilo, že stačí nejaké web sídlo vlastnit' a úspech sa objaví sám. Dnes však vieme, že publikovanie web stránok samo o sebe ešte nič neznamená. Podnikatel' si musí stanovit' realistické a dosiahnutel'né ciele a vypracovat' plán na ich dosiahnutie. Všeobecne sa hovorí, že začat' podnikat' na internete je lacné, ale nie je to celkom tak, hoci je to zvyčajne lacnejšie ako otvorenie tradičnej predajne. Spoločnost', ktorá sa prezentuje na internete prostredníctvom vlastných web stránok, sa vo všeobecnosti už v súčasnosti nepovažuje za vel'mi inovatívnu len z dôvodu jej prítomnosti na webe.

Dôležitejšie je to, ako efektívne túto stránku spoločnost' dokáže využívat'. Pre splnenie očakávaní zákazníkov od prezentácie na internete je dôležité zvážit' mnohé otázky. Pri dnešnom vel'kom počte stránok kl'účovou otázkou by malo byt': akú pridanú hodnotu by mala spoločnost' poskytnút' pre ciel'ového zákazníka na webe? Preto musíme vediet' aj čo treba vziat' do úvahy pred samotným plánovaním. Tu sú niektoré otázky, na ktoré treba odpovedat' pred vypracovaním vášho plánu pre realizáciu elektronického obchodu:

- Kto sú vaši zákazníci, aké sú ich preferencie a kde sa na internete pohybujú? (základná otázka)

- Aká je stratégia vašej spoločnosti pri predaji týmto zákazníkom?

- Č́m je vaša spoločnost', produkt, alebo vaša marketingová stratégia pre web sídlo výnimočná?

- Ako môžu zvýšit' tieto faktory predaj?

- Akú stratégiu použijete na predaj vášho produktu?

- Aké náklady budú spojené s predajom vášho produktu?

- Aké príjmy očakáva spoločnost' počas jedného alebo dvoch počiatočných rokov?

- Aké akcie na podporu predaja prilákajú potenciálnych zákazníkov?

- Aká je miera návratnosti - kol’ko návštevníkov priemerne navštívi stránky pokial' si niektorý z nich objedná?

- Aká je výška investícií potrebných na realizáciu tohto plánu?

Vo všeobecnosti sa spočiatku očakáva výrazný vplyv elektronického obchodovania na sektory ponúkajúce prevažne služby prenosu informácií a dát (poštové, komunikačné služby, rádio a televízia) a poskytujúce informácie (finančné služby, zábavný priemysel, cestovný ruch a burzový makléri). Elektronicky doručované služby, ako je programové vybavenie, služby v cestovnom ruchu, zábavnom priemysle a finančnom sektore sú vedúce odvetvia, kde prevažujú podniky typu firma - firma a firma - koncový zákazník.

\footnotetext{
${ }^{1}$ doc. Ing. Vaculík Juraj, PhD., Ing. Marek Kruppa, Katedra spojov, Fakulta prevádzky a ekonomiky dopravy a spojov, Žilinská univerzita v Žiline, Univerzitná 1, 01026 Žilina, Slovenská republika, tel.: +421415133132 , fax: +421415655615
} 
Z dôvodu nehmotného charakteru takýchto produktov a služieb sa budú musiet' už zavedené pravidlá prehodnotit'. $Z$ tohto pohl'adu má tovar, ktorý je možné prezentovat' vel'mi transparentne a s množstvom informácií najväčší predpoklad na úspech (napr. knihy, hudba, CD nahrávky prostredníctvom audio prehrávačov, malé predmety, ktoré sa dajú l'ahko poslat'). Tovar, ktorý vyžaduje náročnú prezentáciu, napr. vel'mi technicky náročné produkty, je tiež vel'mi vhodné prezentovat' na internete, ak sa marketingové aktivity cielene sústred'ujú na určitú skupinu zákazníkov. Existuje skupina aktivít, ktoré je nutné, v rámci plánovania a realizácie elektronického obchodu, detailnejšie rozpracovat' a to sú napríklad systém predaja, obchodné transakcie, spôsob úhrady za tovar a s tým spojená bezpečnost' systému a v neposledom rade dodávka tovaru a logistika vôbec.

\section{Transakcie}

Zákazník má nákupný košík plný tovaru a ešte ostáva urobit' vel’a práce, kým sa uskutoční prvý obchod. Nemôže sa zákazníkovi poslat' tovar bez toho, aby sa presne vedelo, kol'ko má zaplatit'. A čo je dôležitejšie, je potrebné zistit', či je schopný zaplatit' za svoj nákup. Teda kým sa spracuje nejaká objednávka, musia sa spracovat' doklady podl'a spôsobu platby, ktorý si zákazník zvolil, určit' výšku dane, prepravné náklady, prípadne aj colné poplatky, ak expendujeme tovar do zahraničia.

Dobrou správou je, že mnoho softvérových firiem v poslednom období vytvorilo programové prostriedky na pomerne pohodlné zriadenie obchodnej web stránky. Zlou správou je, že každá firma má svoje špecifické požiadavky na spôsob a formy elektronického obchodovania a tieto požiadavky obvykle nie je jednoduché implementovat' do hotových riešení.

Kl'účovým problémom je vybrat' riešenie, ktoré naviac vyhovuje firme a zákazníkovi a zároveň najlepšie zodpovedá niektorému hotovému aplikačnému balíku. Tu môže byt' problém implementácie priamo na podmienky zákazníka - obecné riešenia nie sú šité na mieru. Druhá možnost' je vytvorit' si takýto software vlastnými silami, čo nie je v niektorých prípadoch tiež reálne.

\section{Možnosti platby}

Existuje vel'a možností spôsobu platby. Vo väčšine prípadov sú transakcie v elektronickom obchodovaní založené na kreditných kartách. Operácie spojené s použitím kreditných kariet sú vel'mi komplexné. Zahŕňajú vel'ký počet nezávislých účastníkov, ako obchodníkov, banky, zákazníkov a ich banky, spoločnosti, ktoré vydávajú kreditné karty a zúčtovacie centrá, kde sa všetky požiadavky stretávajú. Všetky tieto zložky musia spolupracovat' predtým, než sa zákazníkove peniaze dostanú na účet. Aby bol každý v tejto vel'kej skupine účastníkov spokojný, musia sa riadit' určitými pravidlami.

Peniaze sa nemôžu vybrat' z karty skôr než je dodávka doručená, prípadne odoslaná aspoň $v$ ten istý deň. $\mathrm{V}$ bežnej predajni tieto procesy prebiehajú súčasne. Predavač vyžiada platbu z kreditnej karty zákazníka, pričom zákazník si odnáša tovar z predajne. Pri predaji na dial'ku pomocou internetu, sa nemôže požiadat' o prevod peňazí z kreditnej karty, pokým sa neukončí celý proces - výber zo skladu, balenie a odoslanie (pokial' sa nepredáva softvér, alebo iný tovar v elektronickej podobe, ktorý sa dá okamžite doručit' elektronickou poštou). Väčšina transakcií s kreditnou kartou na internete preto funguje nasledovne:

1. Autentifikácia. Je potrebné si overit', či kreditná karta, ktorá bola ponúknutá je platná a nie je hlásená ako ukradnutá.

2. Autorizácia. V tomto procese sa overuje, že z karty môže byt' prevedený dostatok prostriedkov na zaplatenie objednávky. Ako áno, je treba túto sumu rezervovat', ale peniaze ešte nemožno previest'. 
3. Uzavretie transakcie. Akonáhle sa tovar odoslal alebo doručil zákazníkovi, treba to bankám oznámit'. Banka uvol’ní finančné prostriedky, ktoré boli rezervované a peniaze môžu putovat' (aj cez niekol'ko bánk) na účet.

To je spôsob, akým je spracovávaná väčšina transakcií na internete. Celý prenos môže byt' však podstatne komplikovanejší. Treba zvážit' aj ako sa budú vybavovat' reklamácie a vrátenie tovaru, spracovávat' postupné dodávky tovaru a pod. Pri vol'be realizácie platby sa musí počítat' aj s mnohými d’alšími komplikáciami.

Vzhl'adom na množstvo peňazí lietajúcich hore-dole po sieti internetu a hackerov pokúšajúcich sa ich ukradnút', prevládajú obavy o dostatočnej bezpečnosti transakcií medzi zákazníkmi, ako aj obchodníkmi. Existuje už mnoho technických riešení na ochranu týchto transakcií. Aby sa maximálne predchádzalo takýmto problémom, profesionálne aplikácie musia splńnat' súčasné bezpečnostné štandardy.

\section{Metódy platieb}

Kreditné karty

Zatial' najvyužívanejší spôsob platby za výrobky a služby na internete. Zákazník poskytuje všetky informácie z kreditnej karty vyplnením on-line objednávkového formulára. Č́m viac spoločností vystavujúcich kreditné karty obchodník akceptuje, tým je väčšia skupina potencionálnych zákazníkov. Špeciálnym spôsobom ochrany kreditných kariet je VirtualPIN (virtuálne personálne identifikačné číslo). Služba VirtualPIN ponúka dodatočný stupeň bezpečnosti pre zákazníkov obávajúcich sa prezradit' svoje osobné údaje. Spoločnost' Virtual vydáva VirtualPIN zákazníkovi na základe telefonického oznámenia čísla kreditnej karty. Zákazník potom použije VirtualPIN pri transakcii. Pri každom nákupe najskôr Virtual posiela použivatel'ovi e-mailom správu požadujúcu jeho povolenie na spracovanie objednávky a zaslanie tovaru od predajcu.

Nevýhodou používania kreditných kariet je relatívne vysoký poplatok, ktorý musí platit' obchodník aj pri predaji lacných produktov.

Poskytovatelia sofistikovaných bankových služieb v strednej Európe nepopierajú, že trh s kreditnými kartami v porovnaní so západom značne zaostáva. Dôvod rozdielu medzi západom a východom je skôr kultúrny, ako technologický. Vo Vel'kej Británii alebo v Nemecku je viac kariet ako l'udí. Väčšina dospelých vlastní aj Visa aj Mastercard karty, dve najrozšírenejšie značky. V Mad'arsku má karty iba 35\% populácie, v Čechách $16 \%$ a v Pol'sku 10\%. Navyše len 10\% kariet v strednej Európe ponúka kredit, ostatné sú debetné karty. A taktiež len $10 \%$ transakcií predstavuje úhradu oproti výberom hotovosti. Zainteresovaní odborníci predpokladajú, že zavedenie kariet v strednej Európe bude trvat' menej ako 10 rokov. Rýchlost' prechodu na používanie kariet ovplyvnia tri faktory. Najskôr musia l'udia v týchto krajinách zbohatnút', pretože l'udia s nízkymi príjmami potrebujú mat' kontrolu nad svojimi financiami a môžu sa obávat' jednoduchého zneužitia kariet. Obchody a reštaurácie na druhej strane budú musiet' byt' schopné prispôsobit' sa rastúcemu počtu platieb kartami. Banky budú musiet' hl'adat' lepšie spôsoby overovania solventnosti zákazníkov. Po prechode na platby kartami bude možné okamžite zavádzat' platobné systémy elektronického obchodovania. Tento vývoj môže však predbehnút' zavedenie iných platobných systémov vo virtuálnom svete elektronického obchodovania, ako elektronické peňaženky a digitálne peniaze, ktorými chcú obchodníci obíst' potrebu zapájat' do procesu platieb drahé služby bánk.

\section{ATM karty}

Debetné karty (bankomatové karty a platobné karty): Tieto karty sú vel'mi oblúbené v Európe, takzvané "EC karty”. Hlavnou výhodou pre obchodníkov sú nižšie poplatky za transakcie $\mathrm{v}$ porovnaní s bežnými šekmi. 


\section{Nákupné karty}

Majú rovnakú funkciu ako kreditné karty - spoločnost' vystavuje tieto karty svojim zamestnancom na nákup produktov a služieb od vybraných firiem. Očakáva sa, že sa stanú štandardným platobným spôsobom medzi firmami na internete (spôsob obchodovania firmafirma).

\section{Elektronické šeky}

Elektronické šeky majú rovnaké vlastnosti ako bežné šeky. Najjednoduchšie formy týchto systémov vyžadujú od zákazníka vyplnenie formuláru na stránkach on-line predajne. Dáta $\mathrm{z}$ formuláru prijaté obchodníkom sa spracujú (pomocou programu na tlač šekov) v jeho systéme a špeciálny program vytlačí aj šeky. Tento proces s stále momentálne vyvíja, ale existujú spoločnosti, ktoré ponúkajú už kvalitné a lacné systémy na tlač šekov.

\section{Elektronické peňaženky (digital wallets, electronics wallet)}

Definícia elektronickej peňaženky - šifrovací softvér fungujúci ako fyzická peňaženka počas transakcií pri elektronickom obchodovaní. Peňaženka môže obsahovat' údaje platitel'a potrebné na zaplatenie, digitálny certifikát na identifikáciu používatel'a a informácie potrebné na zaslanie tovaru, ktoré umožňujú urýchlenie transakcie.

Pre zákazníka je elektronická peňaženka výhodná, pretože jeho osobné údaje sú šifrovaním zabezpečené proti zneužitiu, niektoré e-peňaženky automaticky vkladajú informácie potrebné na zaslanie tovaru a poskytujú možnost' platby elektronickými peniazmi alebo šekom. Výhoda pre obchodníkov spočíva v získaní ochrany pred podvodmi a zneužitím osobných údajov. Mnoho e-peňaženiek je umiestnených na počítači užívatel'a, no boli vyvinuté verzie tzv. "thin" peňaženky umiestnené na serveri spoločnosti, ktorá vystavila uživatel'om kreditnú kartu. (Netscape a Microsoft v súčasnosti umožňuje podporu technológií e-peňaženiek vo svojich prehliadačoch).

\section{Digitálne peniaze (digital money, digital cash)}

Zákazník aj obchodník musí mat' otvorený účet v banke, ktorá digitálne peniaze vystavuje. Banka dodáva programové vybavenie peňaženky na narábanie s digitálnymi peniazmi. Kredity na klasickom účte sú konvertované na digitálne peniaze a presunuté do programového vybavenia peňaženky, kde sa ukladajú pre následné použitie.

\section{Tradičné metódy platieb}

Elektronické platobné systémy sa stále vyvíjajú ale mnohí zákazníci chcú uskutočnit' platbu tradičným spôsobom, ako sú papierové šeky, dobierková služba, platbou vopred na objednávku respektíve predfaktúru alebo poštovou poukážkou.

\section{Bezpečnostné opatrenia}

Ked' Netscape zaviedol SLL (secure socket layer) vo svojom populárnom prehliadači Navigator v roku 1995, začal dláždit' cestu k širokému verejnému využitiu ochrany on-line komunikácií. SSL je šifrovacia technológia, ktorá správu posiela vo forme, v ktorej ju môže rozlúštit' len príjemca a to s využitím technológie RSA. Internetové adresy (URL), ktoré začínajú https:// využívajú SSL.

Pre on-line obchodníkov to má vel'ký prínos, pretože to redukuje riziká pri on-line transakciách a zvyšuje dôveru zákazníkov. L’udia sú ochotnejší poskytovat' informácie o svojej kreditnej karte ked' sú si istí, že ich okrem obchodníka nemôže vidiet' nikto iný.

Aby sa daná šifrovacia technológia mohla použit' na serveri, je potrebné aby ju administrátor serveru nakonfiguroval a tak umožnil jej využitie. Je tu však problém. Aj ked' je SSL na serveri, spolupracuje týmto spôsobom iba s prehliadačmi, ktoré SSL podporujú. Je 
potrebné, aby ste si zistili, aké prehliadače vaši zákazníci použivajú a podl'a toho zvolit' najvhodnejší post-up. Dnes väčšina prehliadačov túto podmienku splína, okrem niekol'kých starších verzií.

Aby SSL technológia fungovala, je potrebné vlastnit' ID (autentifikačný certifikát) od autorizačnej organizácie, ktorá sa zaručí za identitu. Tento certifikát je niečo ako pas alebo občiansky preukaz. Je to forma identifikácie potvrdzujúca, že niekto dôveryhodný potvrdzuje, že daná osoba, je skutočne tá, za koho sa vydáva.

\section{Ochrana informácií}

Secure sockets layer (SSL) je protokol ochraňujúci dáta posielané z web prehliadača na web server. Web stránky s adresou začínajúcou s „https“ sú prístupné pomocou SSL. Tento systém je používaný v súčasnosti pri všetkých virtuálnych platobných transakciách kreditnými kartami.

Dve hlavné funkcie sú:

- overovací server, ktorý potvrdzuje, že užívatel’ sa nachádza na správnych a pravých stránkach patriacich skutočne spoločnosti, ktorú reprezentujú (napr. program The VeriSign Secure Site Program používaný von-line systéme Tatrabanky https://moja.tatrabanka.sk)

- vytvorenie zabezpečeného toku informácií pomocou kryptografie tak, aby informácie medzi prehliadačom a serverom boli šifrované, čo zabraňuje hackerom čítat' informácie počas ich prenosu.

Secure Electronic Transaction (SET) je štandard umožňujúci bezpečné používanie kreditných kariet na on-line transakcie. SET bol zavedení prakticky všetkými hlavnými spoločnost’ami zaoberajúcimi sa elektronickým obchodovaním, ako Microsoft, Netscape, Visa a MasterCard.

Zavedením elektronických podpisov, SET umožní obchodníkom verifikovat', či nákupca je skutočne osoba, za ktorú sa vydáva. Chránení budú aj nákupcovia pomocou mechanizmu zasielajúceho čísla ich kreditných kariet pri transakciách priamo spoločnosti, ktorá danú kreditnú kartu vydala, na jej overenie a zaplatenie. Obchodník číslo karty nebude vidiet'.

\section{Literatúra}

[1] MAGÁT L’: diplomová práca „E-commerce ako stratégia modernej firmy“, Žilinská univerzita, katedra spojov 2003

[2] TONDR L': Podnikáme s Internetem, Computer Press, Praha, 2002, počet strán: 102, ISBN 80-7226-729-9

[3] MADLEŇÁK R.: Nové modely medzifiremného obchodovania s využitím informačnokomunikačných technológií, Zborník s konferencie, ISBN 80-7100-973-7 